\title{
Physiological Responses of Tomato Plants and Soil Microbial Activity in Salt Affected Greenhouse Soil
}

\author{
Jwakyung Sung, Suyeon Lee, Hyunjung Nam, Yejin Lee, Jongsik Lee, \\ Yaser. A. Almaroai ${ }^{1,2}$, and Yongsik $\mathrm{Ok}^{1}{ }^{*}$ \\ Division of Soil and Fertilizer, NAAS, RDA, Suwon, 441-707, Korea \\ ${ }^{1}$ Department of Biological Environment, Kangwon National University, Chuncheon, 200-701, Korea \\ ${ }^{2}$ Department of Biology, College of Science, Umm Al-Qura University, Makkah 673, Saudi Arabia
}

\begin{abstract}
Crop productivity decreases globally as a result of salinization. However, salinity impact on greenhouse-grown crops is much higher than on field-grown crops due to the overall concentrations of nutrients in greenhouse soils. Therefore, this study was performed to determine the short-term changes in growth, photosynthesis, and metabolites of tomato plants grown in greenhouse under heavily input of fertilizers evaluated by microbial activity and chemical properties of soils. The soils $\left(<3,3.01 \sim 6,6.01 \sim 10\right.$ and $\left.>10.01 \mathrm{dS} \mathrm{m}^{-1}\right)$ from farmer's greenhouse fields having different fertilization practices were used. Results showed that the salt-accumulated soil affected adversely the growth of tomato plants. Tomato plants were seldom to complete their growth against $>10.0 \mathrm{~d} \mathrm{Sm}^{-1}$ level of EC. The assimilation rate of $\mathrm{CO}_{2}$ from the upper fully expanded leaves of tomato plants is reduced under increasing soil EC levels at 14 days, however, it was the highest in moderate or high EC-subjected $\left(3.0 \sim 10.0 \mathrm{dS} \mathrm{m}^{-1}\right)$ at 28 days. In our experiment, soluble sugars and starch were sensitive markers for salt stress and thus might assume the status of crops against various salt conditions. Taken together, tomato plants found to have tolerance against moderate soil EC stress. Various EC levels $(<3.0 \sim 10.0$ $\mathrm{dS} \mathrm{m}^{-1}$ ) led to a slight decrease in organic matter (OM) contents in soils at 28 days. Salinity stress led to higher microbial activity in soils, followed by a decomposition of $\mathrm{OM}$ in soils as indicated by the changes in soil chemical properties.
\end{abstract}

Key words: Electric conductivity, Organic acids, Soluble sugars, Microbial activity, Tomato

\section{Introduction}

Salinity causes significant reductions in growth and yield of many crop plants throughout the world due to soil degradation (Abd El-Azeem et al. 2012; Jung et al. 2011; Ok et al. 2007). However, salinity impact on greenhouse-grown crops differs from that on field-grown crops due to the overall much higher concentrations of nutrients in greenhouse soils. This high ion levels are maintained in the soil to improve quality of the product and to control crop growth under poor light (Sonneveld 2000). Salinity can cause water stress through increasing the osmotic pressure of the soil solution, resulting in much higher concentration of an internal ion and thus leading to plant growth reduction (Greenway and Munns 1980). In particular, water stress by salinity causes deleterious effects on dry matter partitioning, cell extension,

\footnotetext{
Received : 2012. 11. 1 Accepted : 2012. 11. 28

*Corresponding author : Phone: +82332506443

E-mail: soilok@kangwon.ac.kr
}

cell division, and leaf photosynthesis and transpiration (Greenway and Munns 1980; Maas and Hoffman, 1977). Additionally, water stress accumulates sucrose as soluble sugars and starch as carbohydrate in the leaves (Balibrea et al. 2000; Gao et al. 1998; Yin et al. 2010).

Since 1990s, many problems such as the frequent occurrence of soil borne diseases, salt accumulation, degradation of soil quality and decrease in soil productivity have been reported in vegetable greenhousesoils under heavy application of fertilizers with a constant increased greenhouse industry (Chen et al. 2004; Tong and Chen 1991; Xu et al., 2004). More attention has been raised to improve greenhouse vegetable production and minimize salinity adverse effects, however, few studies in relation to the responses of plant and soil to human activities have been done in greenhouse soils compared to the artificially adjusted soils with $\mathrm{NaCl}$. With a consideration of keeping an expansion of greenhouse industry and an input of mineral sources, it might be more productive to understand 
how well plants can perform their own growth features under the conditions of various EC levels.

Therefore, the objective of the present study was to determine the short-term changes in growth, photosynthesis, and metabolites of tomato plants grown in greenhouse soils encountered by heavy input of fertilizers. In addition, the temporal changes in microbial activity and chemical properties of soils were investigated to evaluate soil quality.

\section{Materials and Methods}

Plant Materials and Soil Preparation This study was conducted in a greenhouse at the National Academy of Agricultural Science (NAAS), Rural Development Administration (RDA) in 2011. Soil was collected from farmer's greenhouse fields having different fertilization practices and their chemical properties were analyzed (Table 1). The EC of the collected soils was firstly measured by using an electro-conductivity meter after the extraction of soil solution $(1: 5, \mathrm{w} / \mathrm{v})$, and divided into four EC levels $(<3,3.01 \sim 6,6.01 \sim 10$ and $>10.01 \mathrm{dS}$ $\mathrm{m}^{-1}$ ). The three weeks-old tomato (Lycopersicon esculentum cv. Seonmyoung) seedlings were transplanted with 6 replications into different EC-leveled soils (pot volume: $25 \mathrm{~cm}$ diameter $\times 40 \mathrm{~cm}$ height) after mixing soil thoroughly. Plants were constantly exposed for 28 days with average day temperature of $28 \pm 2^{\circ} \mathrm{C}$ and night temperature of $18 \pm$ $2{ }^{\circ} \mathrm{C}$. Mid-day photosynthetic photon flux density was
$800-1,100 \mu \mathrm{mol} \mathrm{m} \mathrm{m}^{-2}$. The $200 \mathrm{~mL}$ of water was supplied everyday without any application of chemical fertilizer throughout the experiment. Plants and soils were harvested between 10:00 and 14:00 at 14 and 28 days after transplanting, and used for further analysis.

$\mathrm{CO}_{2}$ Assimilation Measurements Photosynthetic activities in response to different $\mathrm{EC}$ levels were measured with a $\mathrm{CO}_{2}$ analyzer (ADC $\mathrm{LCpro}^{+}, \mathrm{ADC}$ BioScientific Ltd, UK) operating in a differential mode. Mid-fully expanded tomato leaves from each treatment were enclosed in the square $\left(6.25 \mathrm{~cm}^{2}\right)$ chamber to monitor $\mathrm{CO}_{2}$ assimilation $(A)$, transpiration rate $(E)$ and stomatal conductance $\left(g_{s}\right)$. Photosynthesis measurement with PPFD (800-1,100 $\left.\mu \mathrm{mol} \mathrm{m} \mathrm{m}^{-2} \mathrm{~s}^{-1}\right)$ and atmosphere $\mathrm{CO}_{2}\left(380 \pm 10 \mu \mathrm{mol} \mathrm{m}{ }^{-2}\right)$ were performed between 10:00 and 14:00.

Metabolites Determination Leaf samples (1g FW) were subjected to $10 \mathrm{ml}$ of $0.5 \mathrm{~N} \mathrm{HCl}(\mathrm{v} / \mathrm{v})$ and heated at $80^{\circ} \mathrm{C}$ for $10 \mathrm{~min}$ with shaking. The extracts were centrifuged $\left(12,000 \times \mathrm{g}, 10 \mathrm{~min}, 4^{\circ} \mathrm{C}\right)$ and passed through $0.45 \mu \mathrm{m}$ membrane filter. Organic acids (citrate, malate and succinate) were determined using HPLC system (Agilent LC 1100, USA). Separation of organic acids was performed for 30 min with an Aminex $87 \mathrm{H}$ column (Temp., $40^{\circ} \mathrm{C}$ ) under $0.01 \mathrm{~N} \mathrm{H}_{2} \mathrm{SO}_{4}$ as a mobile phase. The injection volume of each sample was $20 \mu \mathrm{L}$ and flow rate was maintained $0.5 \mathrm{~mL} \mathrm{~min}^{-1}$. Absorbance was detected with an UV detector for organic acids

Table 1. Soil chemical properties under various EC levels and different soil EC-exposed tomato plants at 14 and 28 days.

\begin{tabular}{|c|c|c|c|c|c|c|c|c|c|c|c|c|c|}
\hline & EC level & $\mathrm{pH}$ & E.C & $\mathrm{OM}$ & $\mathrm{T}-\mathrm{N}$ & $\mathrm{NO}_{3}^{-}-\mathrm{N}$ & $\mathrm{NH}_{4}^{+}-\mathrm{N}$ & $\mathrm{Av} \cdot \mathrm{P}_{2} \mathrm{O}_{5}$ & $\mathrm{~K}$ & $\mathrm{Ca}$ & $\mathrm{Mg}$ & $\mathrm{Na}$ & B \\
\hline & $(\mathrm{dS} / \mathrm{m})$ & $(1: 5)$ & $\left(\mathrm{dS} \mathrm{m} \mathrm{m}^{-1}\right)$ & $\left(\mathrm{g} \mathrm{kg}^{-1}\right)$ & $(\%)$ & - & $\mathrm{mg} \mathrm{kg}{ }^{-1}$ & - & & . & $\mathrm{mg} / \mathrm{kg}$ & (n- & \\
\hline \multirow[t]{4}{*}{ Collected } & $<3.00$ & 6.8 & 1.6 & 33.4 & 0.13 & 10 & 6 & 1,442 & 1.92 & 7.8 & 2.8 & 0.30 & 2.25 \\
\hline & $3.01 \sim 6.00$ & 6.8 & 4.4 & 41.2 & 0.18 & 66 & 6 & 1,275 & 2.74 & 8.6 & 4.1 & 0.70 & 4.27 \\
\hline & $6.01 \sim 10.00$ & 6.7 & 7.5 & 52.8 & 0.23 & 47 & 27 & 1,829 & 3.81 & 10.9 & 5.6 & 1.17 & 7.83 \\
\hline & $>10.01$ & 6.4 & 16.5 & 53.1 & 0.27 & 201 & 29 & 1,652 & 4.08 & 13.6 & 7.4 & 1.88 & 6.63 \\
\hline \multirow[t]{4}{*}{14 days } & $<3.00$ & 6.8 & 1.6 & 33.6 & 0.13 & 20 & 12 & 1,412 & 1.93 & 9.7 & 2.9 & 0.50 & 1.97 \\
\hline & $3.01 \sim 6.00$ & 6.8 & 6.1 & 40.2 & 0.19 & 111 & 12 & 1,397 & 2.77 & 15.3 & 4.7 & 1.14 & 4.59 \\
\hline & $6.01 \sim 10.00$ & 6.5 & 9.5 & 48.3 & 0.23 & 136 & 10 & 1,654 & 3.88 & 15.5 & 6.6 & 1.67 & 8.18 \\
\hline & $>10.01$ & 6.4 & 18.2 & 51.1 & 0.27 & 293 & 11 & 1,666 & 4.90 & 16.8 & 9.2 & 2.77 & 8.04 \\
\hline \multirow[t]{4}{*}{28 days } & $<3.00$ & 6.9 & 2.1 & 31.3 & 0.12 & 13 & 6 & 1,458 & 1.62 & 7.8 & 2.6 & 0.47 & 2.24 \\
\hline & $3.01 \sim 6.00$ & 7.0 & 4.8 & 37.9 & 0.18 & 55 & 22 & 1,476 & 2.27 & 11.3 & 4.1 & 0.98 & 5.07 \\
\hline & $6.01 \sim 10.00$ & 6.6 & 8.4 & 44.3 & 0.20 & 118 & 9 & 1,865 & 3.40 & 12.6 & 6.0 & 1.40 & 8.85 \\
\hline & $>10.01$ & 6.4 & 16.6 & 49.4 & 0.23 & 234 & 9 & 1,602 & 4.30 & 13.1 & 8.0 & 2.32 & 8.57 \\
\hline
\end{tabular}


using a wavelength of $210 \mathrm{~nm}$. Quantification was based

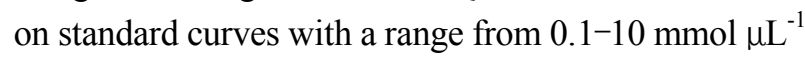
of each standard of organic acids. Acid-soluble carbohydrates were determined using HPLC system (Dionex Ultimate 3000, USA) composed of an auto-sampler and detector (Shodex RI-101, Japan). Separation of carbohydrates was carried out with a Waters sugar-pak (Temp. $75^{\circ} \mathrm{C}$ ) under distilled-deionized water as a mobile phase. The injection volume of each sample was $20 \mu \mathrm{L}$ and flow rate was maintained $0.5 \mathrm{~mL} \mathrm{~min}^{-1}$. Quantification was based on the standard curves of each carbohydrates with a range from $50 \sim 10,000 \mathrm{mg} \mathrm{L}^{-1}$.

Mineral Analysis of Plant and Soil The extraction and measurement of macro nutrients were determined according to Walinga method (1989). Three randomly selected-plants per treatment were divided into leaves, stem, and roots and dried in an oven at $70^{\circ} \mathrm{C}$ for 2 days to determine dry weights and elemental concentrations. Chemical analyses of leaves, stem, and roots were carried out on dry weight basis with three replications. The absorbance of $\mathrm{N}$ and $\mathrm{P}$ was measured at 660 and 880 $\mathrm{nm}$, respectively, using UV-spectrophotometer, while $\mathrm{K}, \mathrm{Ca}, \mathrm{Mg}$, and $\mathrm{Na}$ were measured with ICP-OES (INTEGRA XMP, GBC, Australia).

Soil samples from each treatment were collected from the rhizosphere at 14 and 28 days after transplanting (DAT) in order to examine the changes in inorganic $\mathrm{N}$ and total $\mathrm{C}$ of soil. Inorganic $\mathrm{N}$ was extracted with $2 \mathrm{M}$ $\mathrm{KCl}(1: 5, \mathrm{w} / \mathrm{v})$ from fresh soil samples (Kopp and McKee, 1978; Keeney and Nelson, 1982) and was colorimetically determined by flow injection analyzer (BRAN LUBBE, Germany). Total soil carbon contents were determined using a $\mathrm{CN}$ elemental analyzer (Variomax CN, ELEMENTAR, Germany). The selected chemical properties of soils used in the experiment were determined by the Korean standard methods (RDA, 1988).

Soil Microbial Activity After fumigation and extraction of soil, the released fumigation extractable carbon (FEC) and nitrogen (FEN) were measured using a method modified from Vance et al. (1987). The fumigation time was $24 \mathrm{hr}$ and a $1: 4$ ratio of soil to extractant was used. All extracts were stored at $-20{ }^{\circ} \mathrm{C}$ until analysis. Before analysis, samples were thawed and kept at room temperature for $30 \mathrm{~min}$. Samples were diluted by 5 -folds prior to the determination of extractable C by a TOC analyzer (TOC-5050, Shimadzu, Japan) to prevent precipitation of $\mathrm{K}_{2} \mathrm{SO}_{4}$ from the extraction medium onto the catalyst pellets. Extractable $\mathrm{N}$ was determined as ninhydrin-reactive $\mathrm{N}$, which includes $\mathrm{NH}_{4}-\mathrm{N}$, amines, amino acids, peptides and proteins (Cater, 1991).

Statistical Analysis Statistical analysis was performed with SAS software package (version 9.1). Data were subjected to one-way ANOVA. If the ANOVA yielded a significant $\mathrm{F}$ value $(p<0.05)$, the differences among treatments were compared using a least significant difference (LSD

\section{Results and Discussion}

Plant Growth and Photosynthetic Activities The salt-accumulated soil affected adversely the growth of tomato (Fig. 1) and the difference in growth was observed almost immediately after treatment. The growth rates were the highest in soil EC level below 3.0

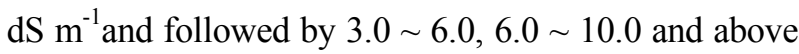
$10.0 \mathrm{dS} \mathrm{m}^{-1}$. However, it was observed that tomato in 3.0 $\sim 6.0 \mathrm{dS} \mathrm{m}^{-1}$ of EC level reached the similar growth rates compared to the below $3.0 \mathrm{dSm}^{-1}$ at 28 days (Fig. 1). This result suggests that tomato plants can resist moderate or high EC soils $\left(3.0 \sim 10.0 \mathrm{dS} \mathrm{m}^{-1}\right)$ and recover their growth at 28 days after early slightly

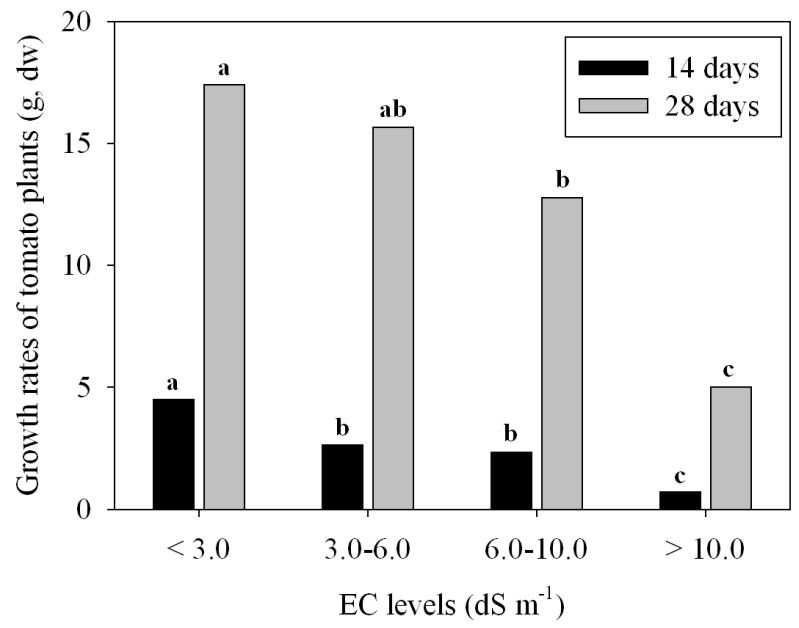

Fig. 1. Temporal changes in the growth of tomato plants under various soil EC levels. Three week-old tomato seedlings were transplanted and harvested to measure shoot dry weight at 14 and 24 days after treatment $(n=6)$. Bars with the same letters are not significantly different at $\mathbf{P}<$ 0.05. 


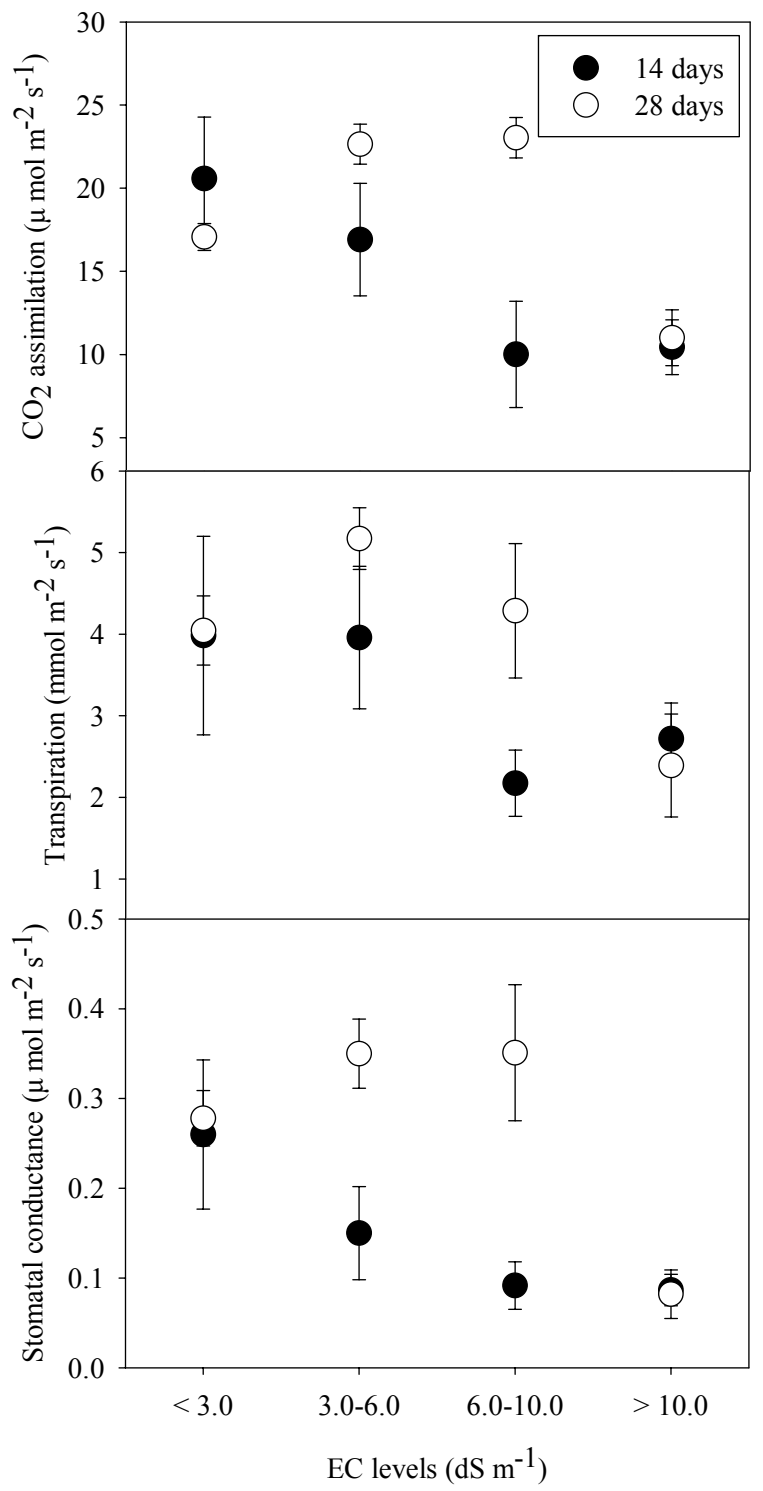

Fig. 2. Temporal changes in $\mathrm{CO}_{2}$ assimilation rates $(A)$, transpiration rates $(E)$, stomatal conductance $\left(g_{s}\right)$ under various soil EC levels. The rate of photosynthesis was measured with Mid-fully expanded tomato leaves between 10:00 and 14:00. Error bars represent the standard deviation of the mean $(n=6)$.

retarded growth at 14 days, while plants were seldom to complete their growth against severe level of EC $(>10.0$ $\left.\mathrm{dS} \mathrm{m}^{-1}\right)$. Many previous studies are in accordance with our present study as they reported decreased growth rates in tomato plants under salt stress (Dumbroff and Cooper, 1974; El-Shourbagy and Ahmed, 1975; Cruz and Cuartero, 1990, Bolarin et al., 1991; Perez-Alfocea et al., 1993).

The measured assimilation rate of $\mathrm{CO}_{2}$ from the upper fully expanded leaves of tomato plants is reduced under increasing soil EC levels at 14 days (Fig. 2), and the range found to be $10.44 \pm 1.65\left(>10.0 \mathrm{dS} \mathrm{m}^{-1}\right) \sim 20.58 \pm$ $3.71 \mu \mathrm{mol} \mathrm{m}^{-2} \mathrm{~s}^{-1}\left(<3.0 \mathrm{dS} \mathrm{m}^{-1}\right)$. In contrast, assimilation rates of $\mathrm{CO}_{2}$ at 28 days were the highest in moderate or high EC-subjected $\left(3.0 \sim 10.0 \mathrm{dS} \mathrm{m}^{-1}\right.$ ) tomato (an average of $22.84 \pm 1.20 \mu \mathrm{mol} \mathrm{m}^{-2} \mathrm{~s}^{-1}$ ), which meant $34 \%$ greater than that in below $3.0 \mathrm{dS} \mathrm{m}^{-1}$ of EC level (Fig. 2). However, there was no change in assimilation rate of $\mathrm{CO}_{2}$ under severe $\mathrm{EC}$ level $\left(>10.0 \mathrm{dS} \mathrm{m}^{-1}\right)$ during the experiment. Likewise, transpiration and stomatal conductance had similar behavior with $\mathrm{CO}_{2}$ assimilation in all treatments (Fig. 2). It is noteworthy from our study that tomato plants found to have tolerance against moderate soil EC stress. The rate of photosynthesis is reduced under salt stress in many NaCl-treated salt stress studies (Seemann and Critchley, 1985; Yeo et al., 1991; Alarcon et al., 1994; Hocking and Steer, 1994). In the present study, the used EC-leveled soils were derived from excessive supply of mineral nutrients, and thus it is assumed that tomato plants are able to withstand high EC levels which can sufficiently cause severe damage evenly at seedling stages.

\section{Concentration of Carbohydrates and Organic Acids} Water soluble carbohydrates, soluble sugars and starch of leaves, stems and roots of tomato were measured at 28 days under different EC treatments (Fig. 3). The contents soluble sugars and starch showed the highest values in below $3.0 \mathrm{dS} \mathrm{m}^{-1}$ of EC, which represented $56.3 \mathrm{mg} \mathrm{g}^{-1}$ in leaves, $91.9 \mathrm{mg} \mathrm{g}^{-1}$ in stems and $58.4 \mathrm{mg} \mathrm{g}^{-1}$ in roots for soluble sugars and $114.9 \mathrm{mg} \mathrm{g}^{-1}$ in leaves, $65.4 \mathrm{mg} \mathrm{g}^{-1}$ in stems and $55.5 \mathrm{mg} \mathrm{g}^{-1}$ in roots for starch. Whereas, no significant differences were observed regarding contents of sugars and starch in above $3.0 \mathrm{dS} \mathrm{m}^{-1}$ of EC levels. Interestingly, the concentrations of soluble sugars (55.1 $\mathrm{mg} \mathrm{g}^{-1}$, roots) and starch (97.4 $\mathrm{mg} \mathrm{g}^{-1}$, leaves) were substantially increased in above $10.0 \mathrm{dS} \mathrm{m}^{-1}$ of EC compared to that in moderate or high $\mathrm{EC}$ regime (3.0 $10.0 \mathrm{dS} \mathrm{m}^{-1}$ ). In addition, a difference in the concentrations of soluble sugars and starch were substantial in leaves and roots while they remained rarely in stems. In our experiment, soluble sugars and starch were sensitive markers for salt stress and thus might assume the status of crops against various salt conditions. There are contradictory results about the effect of salt stress on sugar accumulation. For instance, some studies have reported the increased sugar content (Sacher and Staples, 1985; Balibrea et al., 2000), while others have 


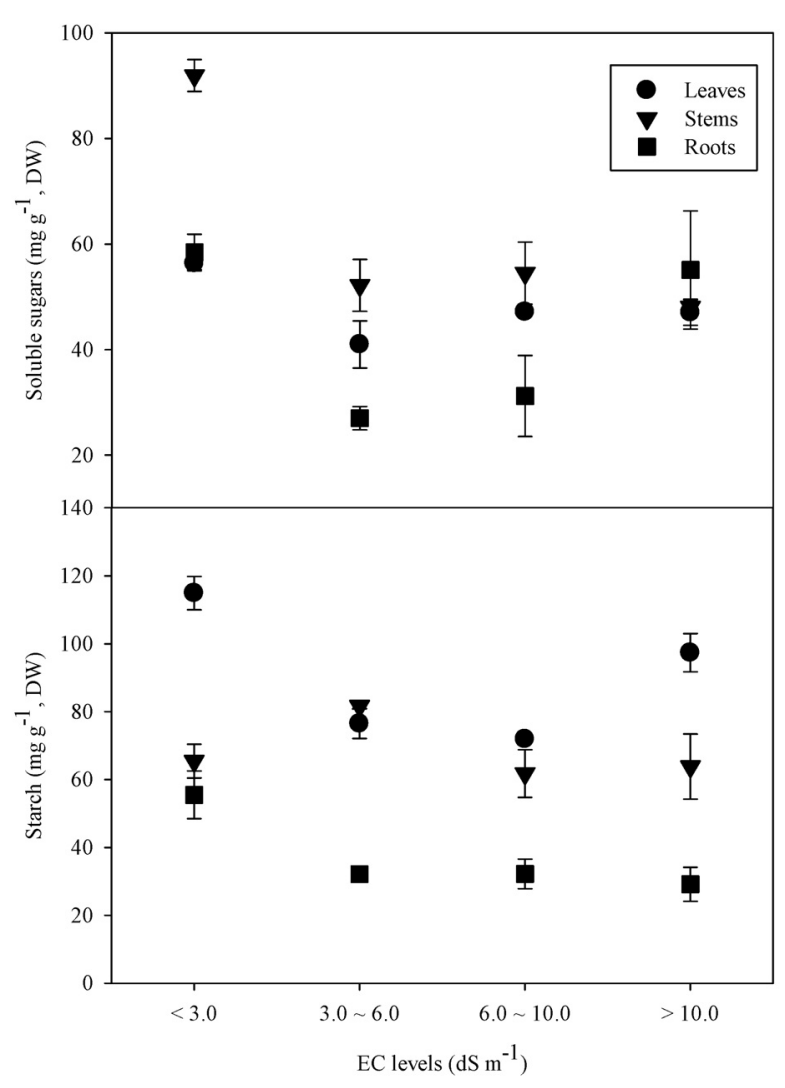

Fig. 3. The concentration of soluble sugars and starch in leaves, stems and roots of different soil EC-exposed tomato plants at 28 days after treatments. Emor bars represent the standard deviation of the mean $(n=6)$.

found a constant or decreased sugar content (Hanson and Hitz, 1982; Morgan, 1992) during stress conditions. Overall, it is obvious that soluble sugars and starch showed a slight decrease in high nutrients-induced salt stress. This result might be assumed that a decline in $\mathrm{CO}_{2}$ assimilation in below $3.0 \mathrm{dS} \mathrm{m} \mathrm{m}^{-1}$ led to an accumulation of soluble sugars and starch through the acceleration of soluble sugar and starch catabolism, opposite to its enhancement in moderate salt stress (3.0 $\sim 10.0 \mathrm{dS} \mathrm{m}^{-1}$ ).

Increasing EC levels induced significant accumulation of citrate $\left(\mathrm{R}^{2}=0.733\right)$ and malate $\left(\mathrm{R}^{2}=0.995\right)$, in the leaves of tomato plants at 14 days (Fig. 4), while the concentration of succinate $\left(R^{2}=0.674\right)$ decreased constantly. Interestingly, all organic acids which measured at 28 days did not represented distinct difference up to $10.0 \mathrm{dSm}^{-1}$ of EC level; however, citrate and malate in high salt regime $\left(>10.0 \mathrm{dS} \mathrm{m}^{-1}\right)$ were substantially accumulated in tomato leaves. Organic acids are rapidly accumulated to regulate cellular osmotic potential against salinity (Perez-Alfocea et al., 1993), and malate

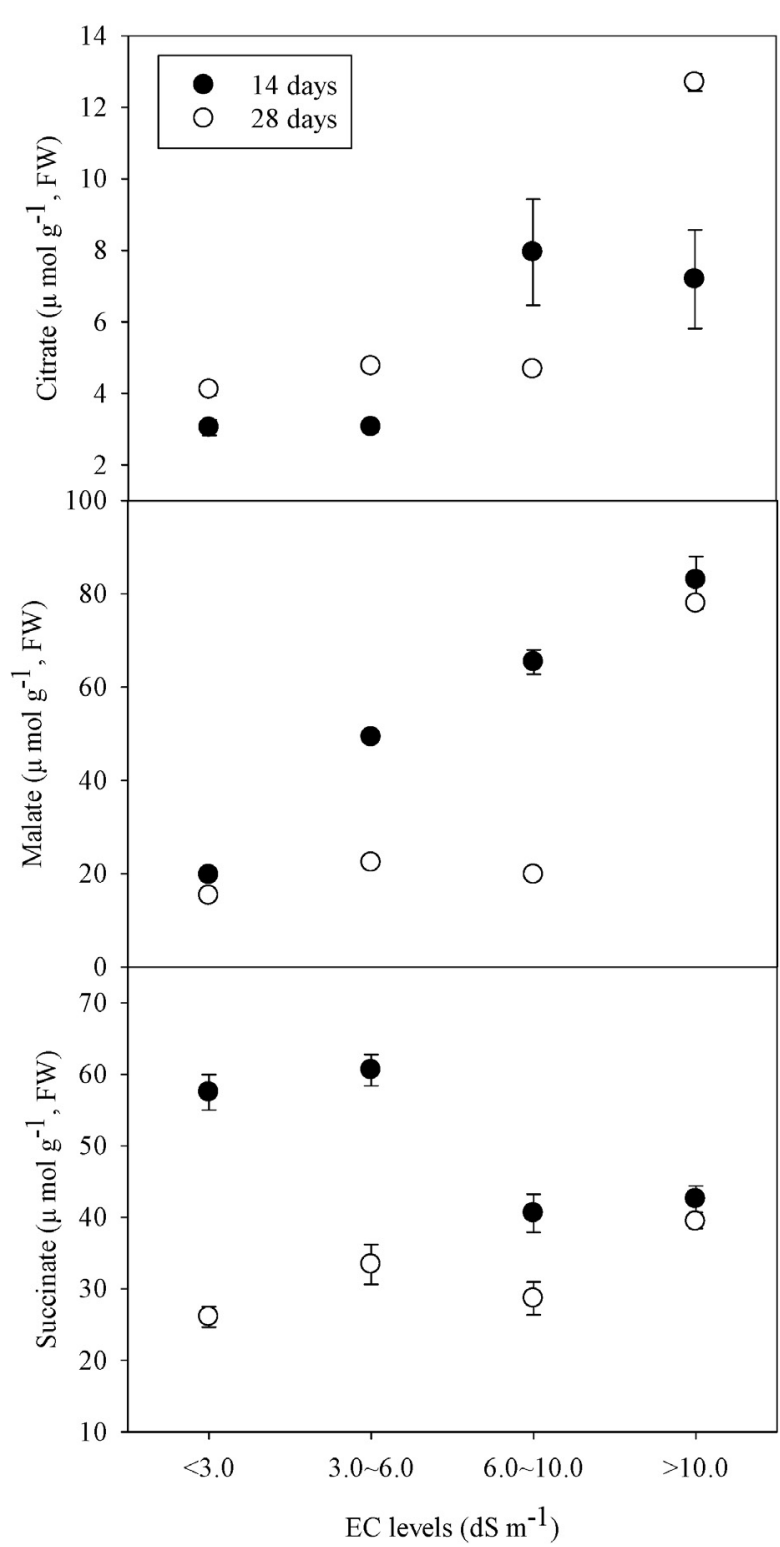

Fig. 4. Temporal changes in the concentration of organic acids, citrate, malate and succinate, in the leaves of different soil EC-exposed tomato plants. Error bars represent the standard deviation of the mean $(n=6)$.

increases substantially as a function of salinity stress (Martinez et al., 1994). In the present study, organic acids accumulation was closely correlated with the concentration of soluble carbohydrates, while a negative correlation between plant growth and photosynthesis was observed.

Plant Mineral Uptake Increasing EC levels influenced significantly the uptake of major elements of tomato plants (Fig. 5). In particular, the contents of $\mathrm{N}, \mathrm{Ca}, \mathrm{Mg}$ and $\mathrm{Na}$ on the basis of dry weight in organs were closely correlated with soil EC while $\mathrm{P}$ and $\mathrm{K}$ were not. The $\mathrm{N}$ 


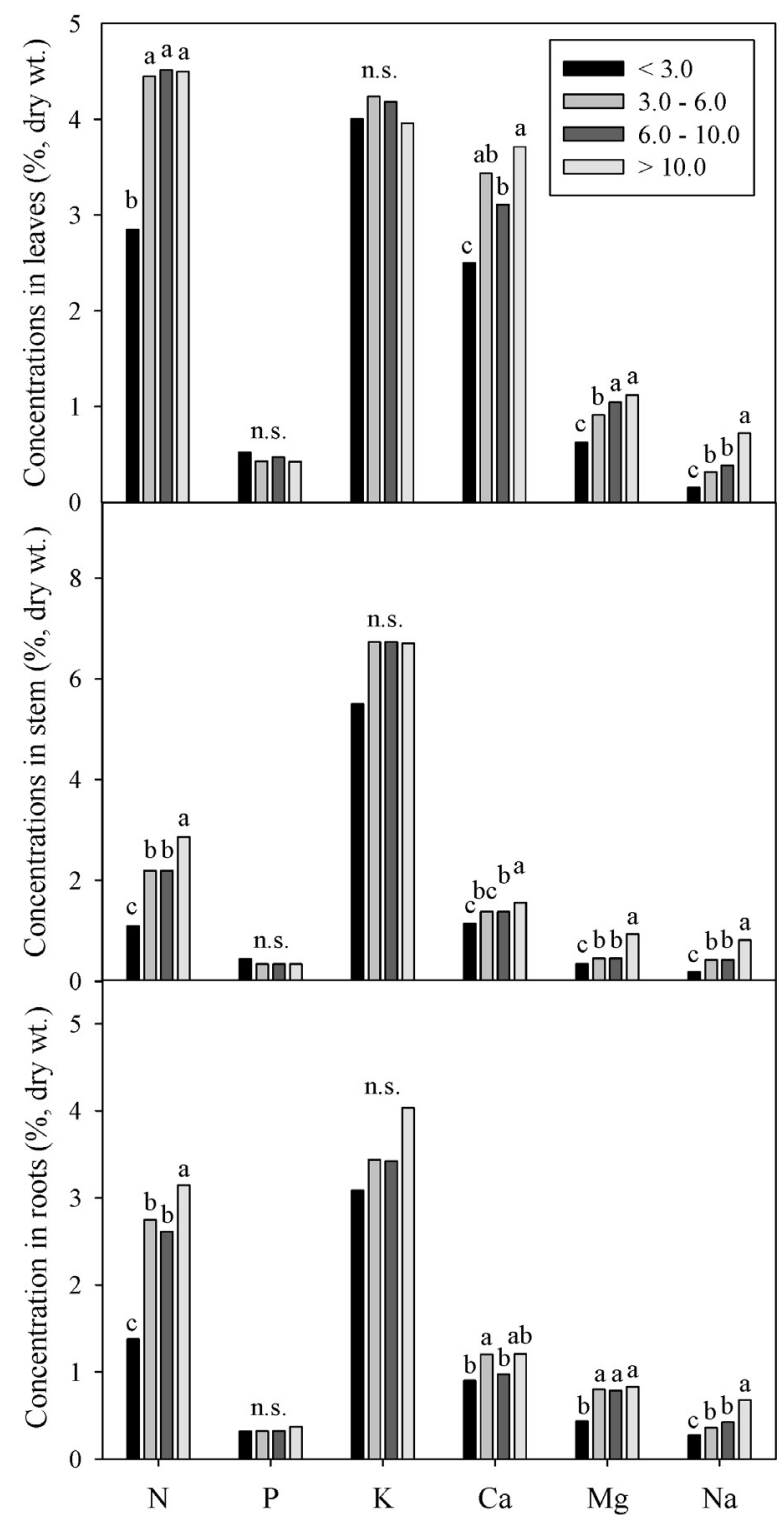

Fig. 5. The concentration of macro elements in leaves, stems and roots of different soil EC-exposed tomato plants at 28 days after treatments $(n=6)$. Bars with the same letters are not significantly different at $P<0.05$.

uptake of leaves, stems and roots at above $3.0 \mathrm{dS} \mathrm{m}^{-1}$ of EC levels was 58 to $120 \%$ higher than the control $(<3.0$ $\left.\mathrm{dS} \mathrm{m}{ }^{-1}\right)$. Contents of $\mathrm{Ca}, \mathrm{Mg}$ and $\mathrm{Na}$ were higher than that in the control by 20 to $37 \%, 64$ to $84 \%$, and 79 to $212 \%$, respectively. In addition, macro elements were mostly accumulated in leaves with the exception of stems where possessed K the highest. Mineral absorption by plants is mainly correlated positively with the application rates of fertilizers at the optimal range. Numerous studies revealed that high salinity has suppressed the uptake of mineral elements such as the reduction in the accumulation of N (Al-Rawahy et al., 1992; Feigin et al., 1991; Khan et al., 1990), P (Sharpley et al., 1992), K (Janzen and Chang, 1987; Sharma, 1996), Ca (Janzen and Chang, 1987; Puntamkar et al., 1988; Rengasamy, 1987) and Mg (Hansen and Munns, 1988; Awada et al., 1995), owing to the competitiveness between ions. Contrary to these previous studies, positive increases in terms of soil ionic compositions with soil EC levels (Table 1) might be suggested that element-excessive soils had little or no effect on limiting the absorption of individual element.

Soil Chemical properties It is clear from Table 1 that increasing EC levels led to a significant increase in concentrations of inorganic $\mathrm{N}(\mathrm{In}-\mathrm{N}), \mathrm{NO}_{3}-\mathrm{N}, \mathrm{Na}$ and $\mathrm{B}$ in soils at 14 and 28 days compared to the control. In addition, $\mathrm{Ca}, \mathrm{Mg}$ and $\mathrm{K}$ concentrations were increased in moderate or high EC soils $\left(3.0 \sim 10.0 \mathrm{dS} \mathrm{m}^{-1}\right)$. Only soil EC has increased in moderate or high EC soils (3.0 $\left.10.0 \mathrm{dS} \mathrm{m}^{-1}\right)$ compared to the control. Various EC levels $\left(<3.0 \sim 10.0 \mathrm{dS} \mathrm{m}^{-1}\right)$ led to a slight decrease in organic matter contents in soils at 28 days and this finding might be assumed that salinity stress affected the microbial biomass, owing to the acceleration of OM decomposition (Table 1).

Microbial Biomass As shown in Fig. 6, all EC levels led to a significant increase of microbial biomass carbon (MBC) and nitrogen (MBN) in soils at 14 and 28 days compared to the control with the exception of MBC in moderate salt stress $\left(3.0 \sim 6.0 \mathrm{dS} \mathrm{m}^{-1}\right)$. In particular, MBC under various EC leveled soils increased by an average of $62.1 \%$ and $36 \%$ at 14 and 28 days, respectively, while a $57.1 \%$ and $180.4 \%$ increase in MBN was observed at 14 and 28 days, respectively, compared to the control (Fig. 6). Our findings prove that salinity stress led to higher microbial activity in soils compared to the control, followed by a decomposition of OM in soils as indicated by the changes in soil chemical properties in Table (1).

Take together, response to salinity stress can be determined by plant growth and its physiological mechanisms of salt tolerance (Vasques et al., 2006). For example, plant can tolerate salt stress by exclusion and accumulation of $\mathrm{Na}^{+}$or $\mathrm{K}^{+}$(Bell and O'Leary, 2003; Peng et al., 2004; Vasques et al., 2006). It is clear from our findings (Fig. 5) that $\mathrm{K}^{+}$is the main cation leading to osmotic adjustment in leaves, stems and roots of different soil EC-exposed tomato plants at 28 days as reported in studies by Matoh et al. (1988), Lissner et al. 

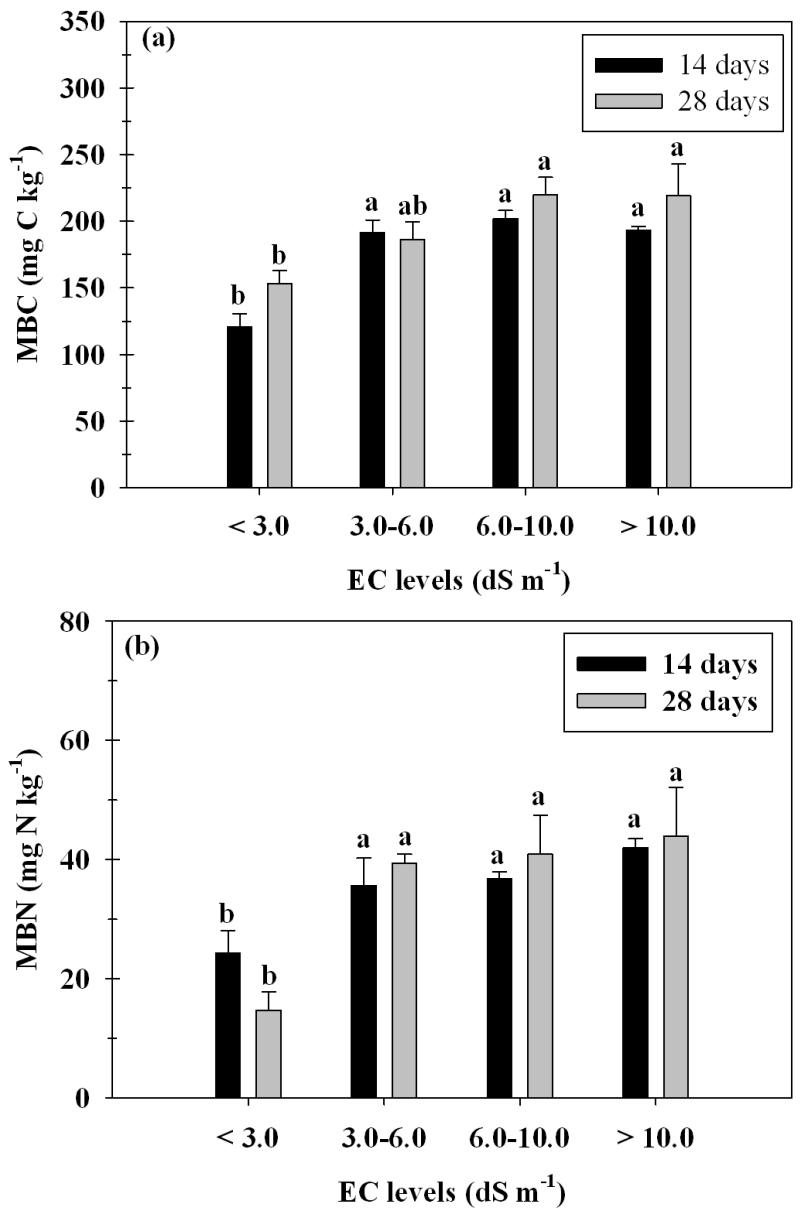

Fig. 6. Temporal changes in microbial biomass carbon (MBC, a) and nitrogen (MBN, b) in different soil EC-exposed tomato plants $(n=3)$. Bars with the same letters are not significantly different at $P<0.05$.

(1999) and Vasquez et al. (2005). Saltinity influenced plant metabolism, resulting in decreased crop growth and yield through osmotic inhibition of the available water uptake by roots or the specific ion affects (Abd El-Azeem et al. 2012; Yang et al. 2009).

\section{Acknowledgement}

This study was funded by the research project (No. PJ008596) of National Academy of Agricultural Science, Rural Development Administration, Republic of Korea.

\section{References}

Abd El-Azeem, S.A.M., M.W.M. Elwan, J.K. Sung, and Y.S. Ok. 2012. Alleviation of salt stress in Eggplant (Solanum melongena L.) by plant-growth-promoting rhizobacteria.
Commun. Soil Sci. Plant Anal. 43:1303-1315.

Alarcon, J.J., M.J. Sanchez-Blanco, M.C. Bolann, and A. Torrecillas. 1994. Growth and osmotic adjustment of two tomato cultivars during and after saline stress. Plant Soil 166: 75-82.

Al-Rawahy, S.A., J.L. Stroehlein, and M. Pessarakli. 1992. Dry matter yield and nitrogen- $15, \mathrm{Na}^{+}, \mathrm{Cl}-$ and $\mathrm{K}^{+}$content of tomatoes under sodium chloride stress. J. Plant Nutr. 15: 341-358.

Awada, S., W.F. Campbell, L.M. Dudley, J.J. Jurinak, and M.A. Khan. 1995. Interactive effects of sodium chloride, sodium sulfate, calcium sulfate, and calcium chloride on snapbean growth, photosynthesis, and ion uptake. J. Plant Nutr. 18: 889-900.

Balibrea, M.E., J.D. Amico, M.C. Bolarin, and F. Perez-Alfocea. 2000. Carbon partitioning and sucrose metabolism in tomato plants growing under salinity. Physiol. Plantarum 110: 503-511.

Bolarin, M.C., F.G. Femandez, V. Cruz, and J. Cuartero. 1991. Salinity tolerance in four wild tomato species using vegetative yield salinity response curves. J. Am. Soc. Horti. Sci. 116: 286-290.

Chen, Z., X.S. Zhang, H.Y. Zhang, P. Christie, X.L. Li, D. Horlacher, and H. Liebig. 2004. Evaluation of current fertilizer practice and soil fertility in vegetable production in the Beijing region. Nutr. Cycl. Agroecosyst. 69: 51-58.

Cruz, V. and J. Cuartero. 1990. Effects of salinity at several developmental stages of six genotypes of tomato (Lycopersicon spp.). In: Cuartero, J., M. L. Gomez-Guillamon, and R. Fernandez-Munoz (Eds.), Eucarpia Tomato 90, Proc. XIth Eucarpia Meeting on Tomato Genetics and Breeding. Malaga, Spain, pp. 81-86.

Dumbroff, E.B. and A. W. Cooper. 1974. Effects of salt stress applied in balanced nutrient solutions at several stages during growth of tomato. Bot. Gazette 135: 219-224.

El-Shourbagy, M.N. and A. M. Ahmed. 1975. Responses of two varieties of tomato to abrupt and gradual short-period sodium chloride exposure. Plant Soil 42: 255-271.

Feigin, A., E. Pressman, P. Imas, and O. Miltau. 1991. Combined effects of $\mathrm{KNO} 3$ and salinity on yield and chemical composition of lettuce and Chinese cabbage. Irrig. Sci. 12: 223-230.

Gao, Z. and M. Sagi and S.H. Lips. 1998. Carbohydrate metabolism in leaves and assimilate partitioning in fruits of tomato (Lycopersicon esculentum L.) as affected by salinity. Plant Sci. 135: 149-159.

Greenway, H. and R. Munns. 1980. Mechanism of salt tolerance in nonhalophytes. Ann. Rev. Plant Physiol. 31: 149-190.

Hanson, A.D. and W.D. Hitz. 1982. Metabolic responses of plant water deficit. Annu. Rev. Plant Physiol. 33: 163-203.

Hansen, E.H. and D.N. Munns. 1988. Effect of $\mathrm{CaSO}_{4}$ and $\mathrm{NaCl}$ on mineral content of Leucaena leucocephala. Plant Soil 107: 101-105.

Hocking, P.J. and B.T. Steer. 1994. The distribution and identity of assimilates in tomato with special reference to stem reserves. Ann. Bot. 73: 315-324.

Janzen, H. H. and C. Chang. 1987. Cation nutrition of barley as 
influenced by soil solution composition in a saline soil. Can. J. Soil Sci. 67: 619-629.

Jung, K., Y.S. Ok, and S.X. Chang. 2011. Sulfate adsorption properties of acid-sensitive soils in the Athabasca oil sands region in Alberta, Canada. Chemosphere 84:457-463.

Khan, A.H., M.Y. Ashraf, and A.R. Azmi. 1990. Effect of sodium chloride on growth and nitrogen metabolism of sorghum. Acta Physiol. Plant 12: 233-238.

Lissner, J., H.H. Shierup, F.A. Comin, and V. Astorga. 1999. Effect of climate on the salt tolerance of two Phragmites australis populations. I. Growth, inorganic solutes, nitrogen relations and osmoregulation. Aquat. Bot. 64: 317-333.

Martinez, V., J.M. Nunez, A. Ortiz, and A. Cerda. 1994. Changes in amino acid and organic acid composition in tomato and cucumber plants in relation to salinity and nitrogen nutrition. $J$. Plant Nutr. 17: 1359-1368.

Mass, E.V. and G.J. Hoffman. 1977. Crop salt tolerance - Current assessment. J. Irr. Drainage Div. 103; 115-134.

Matoh, T., N. Matsushita, and E. Takatashi. 1988. Salt tolerance of the reed plant Phragmites communis. Physiol. Plantarum 72: 8-14.

Morgan, J.M. 1992. Osmotic components and properties associated with genotypic differences in osmoregulation in wheat. Aust. $J$. Plant Physiol. 19: 67-76.

Peng, Y.-H., Y.-F. Zhu, Y.-Q. Mao, S.-M. Wang, W.-A. SU, and Z.-C. Tang. 2004. Alkali grass resists salt stress through high $\left[\mathrm{K}^{+}\right]$and an endodermis barrier to $\mathrm{Na}^{+}$. J. Exp. Bot. 55: 939-949.

Perez-Alfocea, F., M.T. Estan, M. Caro, and G. Guerrier. 1993. Osmotic adjustment in Lycopersicon esculentum and $L$. Pennellii under $\mathrm{NaCl}$ and polyethylene glycol 6000 iso-osmotic stresses. Physiol. Plantarum 87: 493-498.

Puntamkar, S.S., K. Kant, and S.K. Mathur. 1988. Effect of different proportions of $\mathrm{Ca}$ and $\mathrm{K}$ to $\mathrm{Na}$ in saline water on yield and uptake of cations in pearl millet. Trans. Indian Soc. Desert Technol. and Univ. Centre Desert Stud. 13: 91-95.

Ok, Y.S., S.X. Chang, and Y.S. Feng. 2007. Sensitivity to acidification of forest soils in two watersheds with contrasting hydrological regimes in the oil sands region of Alberta. Pedosphere 17:747-757.

Rengasamy, P. 1987. Importance of calcium in irrigation with saline-sodic water-A viewpoint. Agric. Water Manage. 12: 207-219.
Rural Development Administration. 1988. Method of Soil Chemical Analysis. National Academy of Agricultural Science. Korea.

Sacher, R.F. and R.C. Staples. 1985. Inositol and sugars in adaptation of tomato to salt. Plant Physiol. 77: 206-210.

Seemann, J.R. and C. Critchley. 1985. Effect of salt stress on the growth, ion content, stomatal behavior and photosynthetic capacity of salt-sensitive species, Phaseolus vulgaris L. Planta 164: 151-162.

Sharma, S.K. 1996. Effects of salinity on uptake and distribution of $\mathrm{Na}+, \mathrm{Cl}-$ and $\mathrm{K}+$ in two wheat cultivars. Biol. Plant 38: 261-267.

Sharpley, A.N., J.J. Meisinger, J.F. Power, and D.L. Suarez. 1992. Root extraction of nutrients associated with long-term soil management. In: (B. Stewart, ed.) Advances in Soil Science. Vol. 19. Berlin:Springer-Verlag. 151-217.

Sonneveld, C. 2000. Effects of salinity on substrate grown vegetables and ornamentals in greenhouse horticulture. Thesis Wageningen University, Netherlands. pp151.

Tong, Y.W. and D.F. Chen. 1991. Study on the cause and control of secondary saline soils in greenhouse. Acta Hort. Sin. 18: 159-161.

Vasquez, E.A., E.P. Glenn, J.J. Brown, G.R. Guntenspergen, and S.G. Nelson. 2005. Salt tolerance underlies the cryptic invasion of North American salt marshes by an introduced haplotype of the common reed Phragmites australis (Poaceae). Mar. Ecol. Prog. Ser. 298: 1-8.

Xu, F.L., Y.L. Liang, C.E. Zhang, S.N. Du, and Z.J. Chen. 2004. Effect of fertilization on distribution of nitrate in cucumber and soil in sunlight greenhouse. Plant Nutr. Fert. Sci. 10: 68-72.

Yang, J.E., W.Y. Lee, Y.S. Ok, and J. Skousen. 2009. Soil nutrient bioavailability and nutrient content of pine trees (Pinus thunbergii) in areas impacted by acid deposition in Korea. Environ. Monit. Assess. 157: 43-50.

Yeo, A.R., K.S. Lee, P. Izard, P.J. Bourssier, and T.J. Flowers. 1991. Short- and long-term effects of salinity on leaf growth in rice (Oryza sativa L.). J. Exp. Bot. 42: 881-889.

Yin, Y.G., Y. Kobayashi, A. Sanuki, S. Kondo, N. Fukuda, H. Ezura, S. Sugaya, and C. Matsukura. 2010. Salinity induces carbohydrate accumulation and sugar-regulated starch biosynthetic genes in tomato (Solanum lycopersicum L. cv. 'Micro-Tom') fruits in an ABA- and osmotic stress-independent manner. $J$. Exp. Bot. 61 (2): 563-574. 